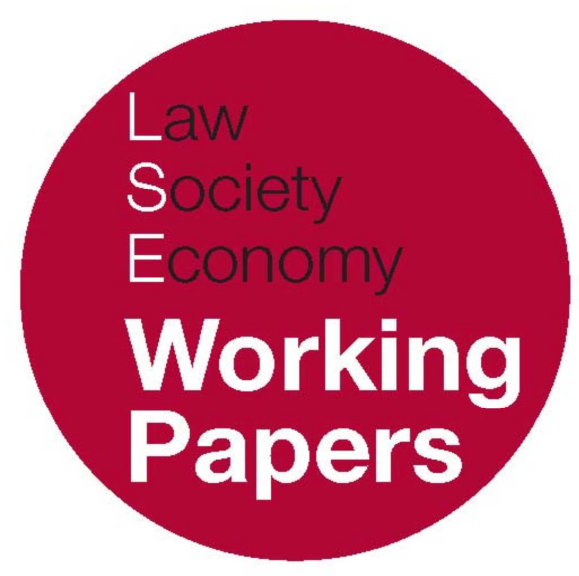

\title{
The Struggle for Legal Reform after Communism
}

A review of Zdenĕk Kühn, The Judiciary in Central and Eastern Europe: Mechanical Jurisprudence in Transformation?

\author{
Jan Komárek
}

LSE Law, Society and Economy Working Papers 10/2014

London School of Economics and Political Science

Law Department

This paper can be downloaded without charge from LSE Law, Society and Economy Working Papers at: www.lse.ac.uk/collections/law/wps/wps.htm and the Social Sciences Research Network electronic library at: http://ssrn.com/abstract=2388783.

(C) Jan Komárek. Users may download and/or print one copy to facilitate their private study or for non-commercial research. Users may not engage in further distribution of this material or use it for any profit-making activities or any other form of commercial gain. 


\title{
The Struggle for Legal Reform after Communism

\author{
A review of Zdenĕk Kühn, The Judiciary in Central and Eastern \\ Europe: Mechanical Jurisprudence in Transformation?
}

\author{
Jan Komárek *
}

\begin{abstract}
The working paper contains an extended review essay of Zdenĕk Kühn, The Judiciary in Central and Eastern Europe: Mechanical Jurisprudence in Transformation? (2011). The central thesis of the book is that 'there is a deep continuity in the methods of legal reasoning employed by lawyers in the region, starting in the era of Stalinist Communism, continuing through the era of late Communism of the 1970s and 1980s and up to the current post-communist period'. In this respect the book's analysis is retrospective, starting in the late nineteenth century, when the Central European legal culture emerged within the 'Austrian legal tradition'. It provides a rich analysis of legal thinking, institutional practices, and expert as well as public discourse concerning judges, courts, and judicial process over the course of the whole of the twentieth century in the region. The book's central argument concerns our time, however. The continuity of Central European legal thinking is, according to Kühn, 'manifested in the problems of the first two decades after the collapse of Communism'. In this regard the book turns to the present and future of Central Europe and becomes missionary, offering a diagnosis together with a prescription. The cure lies, essentially, in catching up with the West and adopting its 'new European legal culture'. More concretely, Kühn argues empathically for the empowerment of the judiciary, which would in his view correspond to the development in the West throughout the second half of the last century.

The result is rather ambiguous. On the one hand, the book is engaging and worth reading for anyone interested in post-communist Europe and its past. The book however serves as an interesting exhibit in the gallery of post-communist legal culture, rather than an accomplished study thereof. In what follows I will firstly introduce the book and then turn to its problematic features, which relate to the (still) prevailing discourse concerning post-communism in Europe.
\end{abstract}

\footnotetext{
* Assistant Professor in EU law, European Institute and Department of Law, London School of Economics and Political Science, J.Komarek@lse.ac.uk. This paper is a book review of Zdenĕk Kühn, The Judiciary in Central and Eastern Europe: Mechanical Jurisprudence in Transformation? (Leiden: Martinus Nijhof 2011).
} 


\section{INTRODUCTION}

The central thesis of Zdenĕk Kühn's book is that 'there is a deep continuity in the methods of legal reasoning employed by lawyers in the region, starting in the era of Stalinist Communism, continuing through the era of late Communism of the 1970s and 1980s and up to the current post-communist period' (p. xv). In this respect the book's analysis is retrospective, starting in the late nineteenth century, when the Central European legal culture emerged within the 'Austrian legal tradition'. ${ }^{1}$ It provides a rich analysis of legal thinking, institutional practices, and expert as well as public discourse concerning judges, courts and judicial process over the course of the whole of the twentieth century in the region. The book's central argument concerns our time, however. The continuity of Central European legal thinking is, according to Kühn, 'manifested in the problems of the first two decades after the collapse of Communism' (p. xv, emphasis added). In this regard the book turns to the present and future of Central Europe and becomes missionary, offering a diagnosis together with a prescription. The cure lies, essentially, in catching up with the West and adopting its 'new European legal culture'. More concretely, Kühn argues empathically for the empowerment of the judiciary, which would in his view correspond to the development in the West throughout the second half of the last century.

The result is rather ambiguous. On the one hand, the book is engaging and worth reading for anyone interested in post-communist Europe and its past. The book however serves as an interesting exhibit in the gallery of post-communist legal culture, rather than an accomplished study thereof. In what follows I will firstly introduce the book and then turn to its problematic features, which relate to the (still) prevailing discourse concerning post-communism in Europe.

\section{THE BOOK}

\section{THE ORIGINS OF CENTRAL EUROPEAN LEGAL CULTURE}

The book starts with a relatively short presentation of the Central European legal culture. It dates back to the early nineteenth century Habsburg Empire, which 'developed a complex system of bureaucracy, an independent judiciary, and above all, a highly sophisticated legal culture' (pp. 1-2), exemplified by large codifications: firstly the General Civil Code (1811) and later procedural codes (1873 and 1895).

\footnotetext{
${ }^{1}$ Kühn does not seem to distinguish clearly between the categories of legal tradition, legal family or legal culture used in comparative law; in this review, I keep the terms used by Kühn in quotations, whereas in my own text I refer to the continental European tradition on the one hand and the Anglo-American tradition on the other. On the genealogy of such classifications and their ideological importance see Mariana Pargendler, 'The Rise and Decline of Legal Families' (2012) 60 American Journal of Comparative Law 1043-1074.
} 
Kühn contends that '[t]he successor states of the Empire inherited from the bureaucratic Habsburg State deep confidence in written law: they believed, and thus sometimes entertained over optimistic expectations, that statutory law could regulate social relations and transform the society through social engineering' ( $p$. 4).

The chapter then turns to institutional issues, focusing on the position of judges, mostly in Czechoslovakia in the inter-war period. Kühn notes their declining status (particularly as regards their salary, but also concerning the scant respect paid to them by the other branches of government). Kühn nevertheless finds, rather optimistically, that ' $[\mathrm{T}]$ he judges honored their independence and understood it as a necessary condition of their activity. When democracy hit a crisis point in Central European in the late 1930s, judges across the region, in sharp contrast to their German counterparts, were one of its most devoted advocates' (pp. 13-14).

The chapter concludes with a short consideration of the experience of World War Two. The author 'believe[s] that the intellectual influence of the [Fascist totalitarian ideology] was unimportant' (p. 17), which was in his view due to the Nazi closure of universities in Poland and the occupied Czech lands. Moreover, 'with the exception of racial and political matters, judges were dealing with the same issues which they had dealt with for decades' (p. 17). Kühn observes that it is remarkable that the liberal conception of law and judicial power was able to survive at least to some extent under [the] oppressive regime' (p. 18). This optimism is tamed at the very end of the chapter, however: 'the Central European nations, ravaged by a brutal war and with it elites decimated, became a much easier target for the incursion of a new political and legal system, Stalinist socialism' ( $p$. 20).

\section{SOCIALIST LEGAL CULTURE IN CENTRAL EUROPE}

In the second chapter the author firstly explains the success of Stalinization of the pre-war legal culture, which he ascribes to 'the communist dominance of the legal academia and the attack on the intellectual independence of the law faculties' ( $p$. 22), together with 'frequent visits by Soviet experts' (p. 23) and the 'isolation from the western legal thought' (p. 23).

Political trials of the 1950s are discussed only briefly, but Kühn emphasizes the 'serious consequences [...] on the minds and consciences of lawyers participating in them' and mentions that ' $\mathrm{t}]$ he stigma of the trials caused general distrust toward judges among a wide public' (p. 27). ${ }^{2}$ A brief overview of the period from the 1960s to the 1980s is then provided, before Kühn discusses the

\footnotetext{
${ }^{2}$ For this contention Kühn, however, refers to an academic work published in Hungary in 1987 and the report of the Dubček [the leader of the reformist fraction in the Czechoslovak Communist Party in 1968] Commission of inquiry - one may therefore ask to what extent the contention is substantiated.
} 
overall transformation of the legal system, which aimed at creating law 'comprehensible to all', in line with the communist ideology. The main reforms concerned the adoption of new civil codes, the inclusion of laymen in the legal system, the restriction of the competence of ordinary courts and the increasing role of administrative decrees, which contributed to the sense that Central Europe was 'leaving the continental tradition' (p. 40), illustrated also by the introduction of the institution of prosecutor - 'the main guardian of socialist legality' (pp. 43- 45). ${ }^{3}$ At the same time, law disappeared from many areas of life, if measured by the number of cases brought to courts, and lawyers continued to lose their prestige. Judicial independence was never fully restored, especially since judges were elected for a relatively short term (in Czechoslovakia) and because of the overall influence of the Communist Party.

The chapter closes with a short reflection on the very existence of a separate socialist legal culture. Kühn seems to agree with those comparatists who doubted it. For example, the 'socialist' civil codes had been introduced into Central European legal systems 'through the indirect route of Soviet law transplants, themselves inspired by the German law of the early twentieth century' (p. 63). The key difference, however, consisted in the ideology underlying the culture. Taking cues from John Hazard's work on socialist law, ${ }^{4}$ Kühn notes:

Socialist law was to serve solely the interest of the Party, which was the only competent authority capable of leading its nation towards the objective of the very existence of the socialist society - a classless community of Communism. Socialist law in this sense might perhaps be closer to the family of religious legal systems, as the element of holy writ (the role of classical writings of Marxism-Leninism in legal reasoning), typical for religious legal cultures, might be spotted in the socialist legal culture (p. 64).

\section{JUDICIAL IDEOLOGY IN COMMUNIST TIMES}

The third chapter forms the central part of the book, occupying almost a third of its overall content. It narrows down the broad picture drawn in previous chapters and deals with judicial methodology or, as Kühn calls it using Jerzy Wróblewski's theoretical framework, the ideology of judicial application of law, or simply judicial

3 In my view, to translate the term 'prokuratura' as 'prosecutor' is misleading, precisely because the prokuratura had a much wider function than just prosecution. On this notion see e.g. Jonathan D Greenberg, 'The Kremlin's Eye: The 21st Century Prokuratura in the Russian Authoritarian Tradition' (2009) 45 Stanford Journal of International Law 1.

4 John N Hazard, Communists and Their Law (Chicago and London: The University of Chicago Press 1969). 
ideology. 5 This ideology 'determines and prescribes the proper method of the judicial interpretation of the law; as well as the ideal role a judge should have in society' (p. 67). Kühn (following Wróblewski) distinguishes three ideologies: the ideology of bound judicial decision-making, which 'maintains that, in their work, judges are fully bound by general rules, which in turn fully control their adjudication' (p. 68). On the opposite side, there is the ideology of free judicial decision-making, which puts 'emphasis on outcomes consistent with some values prevalent in the system (political ideology, religion, the idea of justice, effectiveness etc.), while adherence to general rules is of secondary importance' (p. 68). The ideology of legal and rational judicial decision-making then occupies a compromise position between the two.

Kühn further introduces into his analysis the distinction between formalism and anti-formalism, taking into account both aspects of the style of judicial reasoning and the surrounding environment of the judicial process. First, formalism refers to 'methodological formalism, which reflects the philosophy of textual positivism' (p. 75). 'Textual positivism', another conceptual category used by Kühn, consists, 'in its most extreme form [...] [of] nothing more than the textual exegesis of law' (p. 69). Methodological formalism 'presupposes that - in their reasoning - judges employ arguments of the plain meaning of a statutory text and present their analysis as a sort of inevitable logical deduction from this text' ( $\mathrm{p}$. 75). Secondly, 'formalist reasoning is viewed as a purely mechanical mental operation' (p. 76).

This conceptual apparatus is then put into a wider context, where Kühn argues that in the course of the twentieth century, western law was gradually abandoning formalism and the ideology of bound judicial decision-making, which (according to Kühn) governed in the preceding era (which is placed in the nineteenth century). 'The new European legal culture', ${ }^{6}$ in Kühn's view, rejects clear dichotomies (between binding and non-binding arguments or valid/invalid law). At the same time, this new culture distinguishes between 'hard and easy cases, although it is admitted that the dividing line between these two categories is vague and blurred' (p. 84).

The main bulk of the chapter consists of the analysis of the ideology of adjudication in socialist times. Kühn divides the 40 years of communist rule in Central Europe into two stages. First, the 1950s, where the judge is presented as 'a builder of communism', and second, the period starting some time in the 1960s, where the 'new socialist textual positivism' started to reign. The first, activist era was based on the Soviet idea of law, which was founded on a seeming paradox: 'On the one hand, facing the atmosphere of the building of Socialism, the judicial application of law was clearly activist and anti-formalist. On the other hand, the Stalinist theory of law developed clear textualist, positivist, and formalist features' (p. 94). The paradox is explained, according to Kühn, by the fact that judicial

5 Jerzy Wróblewski (Zenon Bankowski transl and ed), The Judicial Application of Law (Dordrecht: Kluwer 1992).

${ }^{6}$ Here Kühn refers to Martijn W Hesselink, The New European Legal Culture (Deventer: Kluwer 2001). 
activism corresponded to the total mobilization and transformation of society, while formalism and positivism conformed to the Stalinist desire to control the whole of society from the centre - although it clearly contradicted the Marxist thesis about a gradual withering away of the state. This paradox (or contradiction) was solved in a peculiar way: the faithful adherents to Marx were either executed or disappeared (p. 93). Kühn analyses the gradual transformation of judicial rhetoric in Central Europe, which explicitly employed Marxist ideology. This included references to the works of the classics, Marx and Engels and sometimes quotations from speeches by domestic or Soviet communist leaders. Judges 'educated' defendants, while they openly identified socialist law with morality. At the same time they used law instrumentally, especially when they had to apply rules adopted before the communist takeover. The second era of socialist law saw the opposite trend: the retreat from activism. Although 'the official self-perception of communist judges' continued to be 'strongly anti-formalist, as evidenced by frequent reports, directives and statements of the supreme courts' (p. 120), the practice was different, as Kühn demonstrates in a number of examples from Czechoslovak courts. In line with judges, academics started to develop 'the concept of limited law', which supported judicial formalism.

The concept of limited law is another important category borrowed by Kühn from general jurisprudence for the purposes of his analysis. ${ }^{7}$ Kühn looks at legal education and legal scholarship and observes the lack of interest in theories of interpretation. Kühn also looks at the way socialist academics saw western law: in his view, they 'posited a simplified ideal of the western continental legal tradition'. Socialist scholars '[held] onto the ideas of the Continental Law from the nineteenth century and missed the subsequent development of legal thought which took place over a substantial part of the twentieth century' (p. 138). Legislative optimism dominated, as also shown by the ever changing laws (rather than stable codes), whereas case law's role was minimal.

In the rest of the chapter, Kühn addresses the debate on the relationship between judicial methodology and injustice committed through courts and attempts to explain the shift from anti-formalism to formalism. In line with the scholarship that dealt with other authoritarian regimes, Kühn contends that 'both positivism and anti-formalism might contribute to unjust results' (p. 146). ${ }^{8}$

Kühn explains the move from anti-formalism to its opposite by a number of factors. First, referring to Damaška's distinction between two conceptions of judicial authority, coordinate and hierarchical,9 '[i]t is plausible to argue that the

\footnotetext{
${ }^{7}$ See p. 71, fn. 24, where Kühn acknowledges that he 'borrowed the term from, and ha[d] been inspired by' David Lyons, 'Justification and Judicial Responsibility' (1984) 72 California Law Review 178.

${ }^{8}$ See particularly Vivian Grosswald Curran, 'Fear of Formalism: Indications from the Fascist Period in France and Germany of Judicial Methodology's Impact on Substantive Law' (2002) 35 Cornell International Law Journal 101.

9 See Mirjan R Damaška, The Faces of Justice and State Authority; A Comparative Approach to the Legal Process (New Haven and London: Yale University Press 1986), 16-46.
} 
judiciary of the early communist times was based on the shared ideals of an omniscient Marxism-Leninism, knowledge of which was alone believed to generate the only right answer, superior to the formalistic answers produced by 'bourgeois' civil proceedings' (p. 153). The turn to formalism could then result from communist judges' 'disenchantment with Marxism-Leninism' (p. 154). Second, 'most legislation was already enacted by the socialist state, so that there was no reason for socialist judges to attempt to rewrite these socialist laws' (p. 155). Third, in Kühn's view, '[o]ne should not forget that post-Stalinist formalism was also reaction to the Stalinist misuse of law' (p. 156), which relates to the fourth point, the reaction of the general public, that 'accustomed to the legalism of the former bourgeois era, [was] shocked by the extent of anti-formalism exhibited by the Stalinist judiciary' (p. 157). Fifth, the Stalinist 'emphasis on [legislative] norms and state coercion' (p. 158) favoured formalism and the ideology of bound judicial decision-making, rather than activism. Sixth, the 'strictly literal positivist reasoning might in fact function as a protective shield against the charge of deviating from the party line' (p. 158).

The chapter's conclusion highlights the backwardness of socialist law: 'It appears that Marxism-Leninism generated a significant time lag in the intellectual development of Central and Eastern Europe which could not be overcome within the first post-communist decade' (p. 160). This is shown by socialist scholars' attachment to the ideas of continental European tradition, which had for long been outdated and swept away by the 'new European legal culture'. 10

\section{AFTER THE COLLAPSE}

The final two chapters deal with the period after the collapse of Communism until the accession of the Central European countries to the EU. Chapter 4 briefly describes the challenges facing judges in these countries, mostly in institutional terms. Chapter 5 then analyses the period of transformation and forms a counterpart to chapter 3, both in depth and the scope of its analysis, occupying similarly more than a third of the whole book.

Chapter 4 looks at the position of the judiciary after 1989: the extent to which the personnel could be replaced. There, Kühn finds that 'already in the beginning of the twenty-first century the number of judges who had served on the bench before 1989 is low' (p. 165), which, however, due to the continuity of the 'type of judicial thinking' did not mean that his analysis of socialist judges was not relevant for our understanding of the present condition of the Central European judiciary (p. 166). At the same time, while the ordinary judges remain professional career ones, coming to the bench soon after graduation and having relatively lower prestige (p. 170), a completely new type of actor enters the scene: constitutional

10 See particularly pp. $138-141$ and 159-161. 
justices at newly established constitutional courts. There, in Kühn's view, 'we can find outstanding figures able to give the Court's reasoning appropriate direction toward sophisticated western style adjudication' (p. 175).

Their importance comes to light in chapter 5 , a significant part of which is devoted to the intercourse ${ }^{11}$ between the Czech Constitutional Court and ordinary courts and the challenge the former has presented to the ideology of bound judicial decision-making. Kühn claims that the old philosophies of the bound application of law and textual positivism continue to govern the post-communist legal and judicial discourse and that, in some ways, their features have even worsened' (pp. 189-190). Kühn concentrates on a number of issues indicating the persistence of the old socialist judicial ideology.

Firstly, in Kühn's view, '[o]ne of the major problems which post-communist ordinary courts have faced is the inability to grasp the complexity of hard cases [p. 201]. The judges 'implicitly follow the presumption that it is possible to decide any case in a textual fashion. [They] try to follow the letter of the law, however problematic and absurd the results this course produces (p. 201). They are not assisted by legal scholars, who remain imprisoned in the 'old fashioned positivistic doctrine, which [in Kühn's view] is nicely captured in David Lyons' term, the theory of limited law, or Roscoe Pound's, “mechanical jurisprudence" (p. 208). ${ }^{12}$ This is demonstrated by the continuing scepticism concerning teleological reasoning (p. 200), the '[i] nability to engage in creative judicial decision-making' (p. 207), the lack of 'legal education in, and notions of, creative interpretation' (p. 208). Post-communist judges also hesitate to 'apply general clauses of the codes or general principles of law' (p. 209). They fail to understand the notion of 'persuasive sources', whereby '[i]n a simplified intellectual world of limited law, everything is either binding (therefore legally relevant) or non-binding (and, therefore, legally irrelevant)' (p. 210). Kühn also notes the absence of any meaningful discourse between the judiciary and academia (pp. 212-215) and finally turns to the problem of precedent.

Here, on the one hand, the continuing denying of the binding force of precedent 'would not, in itself, be tragic because such a view is not uncommon even in western Europe' (p. 217), but '[b]ecause any persuasive sources of law are beyond the ken of many socialist scholars and judges, precedent is rather weightless' (p. 218). On the other hand, Kühn notes the continuing existence of '[j] udicial interpretational statements, specific instrument of judicial law-making par excellence developed in Central Europe during the communist era, [that] are issued by supreme courts on a certain legal issue in order to unify the conflicting case law' (p. 218). The importance of the Czech Constitutional Court is emphasized again, since it 'perform[ed] the function which should have been,

11 Kühn calls it a 'discourse'. Due to the one-sidedness I suggest 'intercourse' is a more appropriate characterization.

12 Referring to Lyons, n 7, and Roscoe Pound, 'Mechanical Jurisprudence' (1908) 8 Columbia Law Review 605. 
under normal conditions, exercised above all by legal scholars' (p. 200). This is documented by numerous examples of the Constitutional Court's decisions, addressing all the problems identified by Kühn.

Some of the methodological questions became a topic of public discourse in the Czech Republic, as is illustrated by the debates surrounding the nominations of some constitutional justices, where President Havel intervened on the Senate and condemned 'the conception of law prevailing in the post-communist period' (p. 227). Attention is also paid to the question of the binding force of constitutional courts' precedents, which relates to the problem of what Kühn sees as an 'over-centralization' of centralized constitutional review': the insistence of constitutional courts on their monopoly on controlling the constitutionality of other legal norms, which runs against the 'philosophy of new constitutionalism'. After an extensive discussion of the Czech and Polish constitutional courts' conflicts with ordinary supreme jurisdictions, Kühn concludes that preserving the centralized model is still preferable, due to the self-understanding of ordinary judges as civil servants, their educational background and, finally, the lack of a formal doctrine of stare decisis (pp. 260-263).

Kühn briefly touches on the issue of the use of comparative law ('an extremely important component of [constitutional courts'] judicial politics $-\mathrm{p}$. 264) in order to conclude this chapter with an overview of how Central European judges (will) cope with European law. It includes both the period before accession and shortly after it (given the fact that the book was finished in 2006). He analyses the first decisions of constitutional courts (a prominent place is given to an analysis of the decisions of the Czech and Polish constitutional courts concerning the European Arrest Warrant), then turns his attention to ordinary courts. Here he is not at all optimistic: ' $\mathrm{u}]$ nless Central European legal and judicial methodology, which approaches the ideal of mechanical jurisprudence, is radically modified and made more open to teleological argumentation, the application of Community law might face serious obstacles from lawyers unable to reason about the law's rationale and purpose' (p. 281).

In the concluding chapter Kühn comes back to the question whether a specific Central European, formerly socialist, now perhaps post-communist, legal culture exists. He observes that 'when lawyers and academics from postcommunist countries meet, they always find that, regardless of which country they come from, they are all beset by a common set of problems' (p. 293). Most of these problems, in Kühn's view 'relate to the excessive formalism of postcommunist law and to the specific type of authoritarian legal culture based on many old-fashioned, Continental legal myths' (p. 293). 'The empowerment of the judiciary via the European Enlargement might be considered a sort of treatment for many [such] problems' (p. 294), which will require 'a new ideological conception of the judicial function' (p. 294). Although he acknowledges the importance of the proper level of judicial self-restraint (p. 295), Kühn concludes his book with a quotation from Tocqueville: 'as long as the process of judicialization is generally considered "one of the most powerful barriers that has 
ever been devised against the tyranny of political assemblies", the judicialization of politics is likely to continue' (p. 296). ${ }^{13}$

\section{THE MISERY OF CATCHING UP WITH THE WEST}

Central Europe is facing a populist or even authoritarian backlash, which is following the period of 'democracy fatigue' that enveloped the region when it joined the EU. ${ }^{14}$ Simplistic accounts would ascribe this phenomenon to the backwardness of post-communist countries, which were still looking back to nineteenth century nation-building rather than to twenty-first century transnational integration, the destination of Europe's West. ${ }^{15}$ According to this 'backwardness thesis', the present problems, particularly the disenchantment with democracy, the high level of corruption and the weak rule of law, are the surviving symptoms of post-communist Europe's past and will be overcome once the region finally catches up with the West.

A different consciousness emerges in post-communist Europe however: that its 1989 revolutions were somehow taken away from the people of postcommunist Europe who never got control over their lives. ${ }^{16}$ Liberal democracy coupled with market economy was presented to them as the only alternative, since 'third ways', trying to find a compromise between socialism and capitalism, would have led to the third world, as the chief architect of the Czech transformation, Václav Klaus, once quipped. ${ }^{17}$ More critical accounts of the post-1989 period thus show how the collapse of communism helped to cement the dominant politicaleconomic order of the last twenty years, which now goes under the name of neoliberalism - and has become contested in the last few years. ${ }^{18}$

If we accept the latter narrative, rather than that of post-communist Europe's backwardness, the present 'populist backlash' can be seen as a reaction to the suppression of many social conflicts, which were contained in the name of the

\footnotetext{
${ }_{13}$ Quoting Alexis de Tocqueville, Democracy in America. Book I (New York: Vintage Books 1945 [1835]), 107.

${ }^{14}$ See e.g. special issue of (2007) 18 Journal of Democracy, Number 4.

${ }^{15}$ See Ralf Dahrendorf, Reflections on the Revolution in Europe (New Brunswick and London: Transaction Publishers 2005 [c]]), 149-150 (Dahrendorf himself did not fully endorse the claim).

${ }^{16}$ For a forceful statement see Boris Buden, Zone des Übergangs: Vom Ende des Postkommunismus (Frankfurt am Main: Suhrkamp 2009).

17 'Third Way, No Way?', Notes for the World Economic Forum, Davos, 26 January 2000, referring to Klaus' 1990 Davos speech, available at http://www.klaus.cz/clanky/1186, last accessed on 31 January 2014.

${ }^{18}$ See particularly Johanna Bockman, Markets in the Name of Socialism: The Left-Wing Origins of Neoliberalism (Stanford: Stanford University Press 2011). The term 'neoliberalism' is now used in ideological battles much like 'communism' used to be, and it is notoriously difficult to define neoliberalism today; see e.g. Philip Mirowski, 'Postface: Defining Neoliberalism' in Philip Mirowski and Dieter Plehwethe (eds), The Road From Mont Pèlerin: The Making of the Neoliberal Thought Collective (Cambridge, Mass and London: Harvard University Press 2009), 417-455.
} 
Return to Europe. To really understand the present problems of post-communist Europe requires more open engagement with their communist past, which rejects the simple triumphalism of the early post-1989 period. The book under review does not offer such an analysis; sometimes its findings are based on rather weak evidence. The book also presents the West as the unquestionable destiny of the post-communist countries and, finally, it seeks to condemn the period of communism and the people involved in it, rather than to understand them. In what remains I discuss these shortcomings in detail.

\section{THE PERILS OF 'GOING BEYOND TEXTS'}

While one may agree with Kühn that 'the methodological issues [cannot] be explained by analyzing the texts of judicial decisions and works of legal theory alone' (p. xviii), the book is weakest precisely where it transcends these textual sources. This problem concerns all periods under examination, although to a different extent and with different effects.

When Kühn rather boldly praises Central European judges' attachment to the ideals of judicial independence and democracy, the only evidence concerning Czechoslovakia (or its Czech part) comes from Kühn's reading of the Czechoslovak judicial journal, which was 'firm in its rejection of totalitarianism' (p. 14, fn. 63). In my view, one cannot come to such conclusion based on the kind of evidence Kühn brings in: a report from a conference of the professional organization of Czech judges published in their professional journal, which took place several months after the occupation, or a single decision of the Czech Constitutional Court from the same period (p. 18).19 In fact, a serious study of how the Nazi occupation (and the existence of an independent Slovak state, which was in fact satellite to Hitler's Germany) affected legal culture in Czechoslovakia (or more widely, Central Europe) is still missing.

More problematically, the book glosses too quickly over a troubling period between the end of the Nazi occupation in May 1945 and the communist takeover in February 1948, when a relatively autonomous Czechoslovak government contributed no less than communists supported from the Soviet Union to the decline of democracy and the rule of law. ${ }^{20}$ In particular, the post-war retribution against 'Nazi collaborators' left a deep mark on Czechoslovak legal and political culture, with its manifest violations of due process rights, especially the right to fair trial, right to defence and judicial independence - viewed even by then postwar standards.

\footnotetext{
19 The book which Kühn refers to and which purports to be a 'historical study' uses the same 'evidence'. See Pavel Maršálek, Protektorát Cechy a Morava [Protectorate Bohemia and Moravia] (Prague: Karolinum 2002).

${ }^{20}$ For a general account of that period see Benjamin Frommer, National Cleansing: Retribution against Nazi Collaborators in Postwar Czechoslovakia (Cambridge: CUP 2005), chapter 1.
} 
For the socialist period Kühn selects decisions published in the Czechoslovak official reporter of judicial decisions, which replaced various forms of semi-private reports existing before the war. This official reporter 'covered only a small portion of judicial decisions, including only those carefully scrutinized by the editorial body of the reporter, later also in co-operation with the ministries and law schools' (p. 128). In the light of this, however, it is difficult to portray convincingly the mentality of the whole judiciary and its transformation, as Kühn does in the 'empirical' section of chapter 3. Moreover, Kühn himself mentions the critique by communist ideologues of decisions of ordinary courts, which naturally did not get into the official reporter (p. 104). The question then arises, what was really going on in the Czechoslovak judiciary of the time: Stalinization, or an opposition to it by the professional judges who were allowed to stay on the bench even after the communist take-over of power? And if both (as seems to be the case), what was the proportion between the two?

The 'empirics' is even more problematic when generalizations are made from few decisions, coming from different countries. At one place Kühn for example states that ' $[\mathrm{t}]$ he opinions of many courts [were] full of Marxist slogans', while referring to one decision of the Polish Supreme Court (p. 103) and an example from a regional court from Czechoslovakia. How representative are these and how was the selection made?

In the chapter concerning post-communist transformation, the 'selection bias' is different, but no less problematic: Kühn looks at the Czech Constitutional Court's decisions reviewing ordinary courts, which in many instances would be the decisions of the Supreme Court only, ${ }^{21}$ since judicial remedies must be exhausted before a constitutional complaint can be lodged. This can hardly give a realistic picture of what was really going on in the judiciary as a whole, since only a handful of decisions of all courts in the Czech Republic ever get to the Constitutional Court. The harsh critique of the state of legal culture in the Czech Republic then can seem rather problematic, especially when it is extended to other countries in the region.

The method of selecting material to support a more conceptual analysis in all periods thus seems to be governed by the desire to come to a conclusion which was established earlier. It can be too demanding, perhaps, to ask the author to concentrate on one country and study the archives containing thousands of decisions (as a serious study of a legal culture and its history requires), but it would be fair to acknowledge the limitations of the approach ultimately adopted more openly and moderate the categorical, if not directly condemnatory, language which

21 The Czech Supreme Administrative Court started to operate only in 2003. 
pervades the book.22 This applies even more to Kühn's treatment of 'Western Law' and its use as a normative ideal for post-communist legal reform.

\section{THE WEST AS THE PROMISED LAND}

In Kühn's view, the socialist legal culture had adopted 'a simplified ideal of the Western Continental legal tradition' (p. 138), which then remained in the minds of most judges and scholars after the collapse of their communist regimes (chapter 5, passim). Incidentally, this 'outdated' or 'old-fashioned' view corresponds to how the continental European legal tradition is sometimes described in Anglophone works. Judges are thus denied the power to make law in whatever sense; they are entirely subordinated to the legislature and statutes; and they do not know how to deal with precedent (they do not have a proper 'case law method'). ${ }^{23}$ The French in particular are the favourite targets of such (mis-)characterizations, as evidenced by Mitchel Lasser's Judicial Deliberations (used extensively by Kühn), ${ }^{24}$ but Germans did not escape similar mischaracterizations either. ${ }^{25}$ The 'new European legal culture' comes to the rescue, however, calling for a 'creative approach to judicial law-making' (p. 79), provoked by the growth of state powers and the regulatory state. ${ }^{26}$

One can indeed be puzzled why this version of the history of continental European law still survives, in the light of the already existing studies which show quite the opposite, as regards both the place of judges and judicial law making ${ }^{27}$ and the broader conceptions of $\mathrm{law}^{28}$ in the nineteenth and the early twentieth

\footnotetext{
${ }^{22}$ See for the same kind of hesitations the review of Ingo Müller (Deborah L Schneider transl), Hitter's Justice: The Courts of the Third Reich (Cambridge: Harvard University Press 1991) by Richard Posner, 'Courting Evil' The New Republic 17 June 1991, pp. 36-42, particularly at 40.

${ }^{23}$ For a critique of such derogatory views see Jan Komárek, 'Reasoning with Previous Decisions: Beyond the Doctrine of Precedent' (2013) 61 American Journal of Comparative Law 149.

${ }^{24}$ Mitchel De S.-O.-L'E Lasser, Judicial Deliberations. A Comparative Analysis of Judicial Transparency and Legitimacy (New York: OUP 2004). See my review article, 'Questioning Judicial Deliberations', (2009) 29 Oxford Journal of Legal Studies 805.

25 Here the main 'culprit' seems to be an otherwise admirable book by Franz Wieacker (Tony Weir transl), A History of Private Law in Europe with Particular Reference to Germany (Oxford: Clarendon Press 1995), also extensively used by Kühn.

${ }^{26}$ See text to $\mathrm{n} 6$

${ }^{27}$ Kühn notes that his 'explanation presents a danger of inevitable simplification and even a caricature' (p. 78, fn. 58) and refers to Regina Ogorek, Richterkönig oder Subsumtionsautomat?: Zur Justiztheorie im 19. Jabrbundert (Frankfurt am Main: Vittorio Klostermann 1986), but his whole account does not seem to have taken this book seriously. The book's main findings were summarized by Regina Ogorek thus: 'the logical-mechanical view of judicial activity as the part of legal doctrine which was concerned with the rules of statutory interpretation could possibly be traced back as a marginal phenomenon at the beginning of the [nineteenth] century, and in any event as a late product of the codification movement', Regina Ogorek, 'Inconsistencies and Consistencies in 19th Century Legal Theory' (2011) 12 German Law Journal 34, 56. For an account concerning the French judiciary, see e.g. Jacques Krynen, L'État de justice, France XIIIe-XXe siècle. Tome 2 : L'emprise contemporaine des juges (Paris: Gallimard 2012).

${ }^{28}$ See particularly Kaarlo Tuori, Ratio and Voluntas: The Tension between Reason and Will in Law (Farnham: Ashgate 2011), with numerous references to works that seem to accord better justice to 'conceptualists' or 'formalists' of the nineteenth century.
} 
centuries. One explanation can be that these caricatures are quite effectively employed to delegitimize views resembling those which long ago were rejected in the progress of history. Nobody would want to look 'old-fashioned' or 'outdated'. These are characterizations often ascribed to the contemporary actors of post1989 transformation and their views; they were sceptical of the extensive law making power of judges, the ideas of 'New Constitutionalism' (another brand on offer from the West) and the belief that 'rational' judicial decision making is less arbitrary than 'formalist' or 'positivist' one, rejected by 'progressivists'.

Here we can find interesting parallels to a similar phenomenon known from other legal systems: American legal realists' mischaracterizations of 'formalists'29 or the invention of the term Begriffurisprudenz' ('conceptual jurisprudence') by 'its' critics such as Rudolf von Jehring. ${ }^{30}$ The use of Pound's term 'mechanical jurisprudence' is quite indicative of Kühn's reformist agenda. ${ }^{31}$ There is in fact little serious interest in the actual intellectual world of lawyers during communism. Instead, derogatory labels, such as the 'simplified intellectual world of limited law' (p. 210) are used.

This can be nicely illustrated by Kühn's treatment of one of the central themes of his criticism of both socialist and post-communist law: the problem of precedent and judicial law making. At one place the author criticizes the continuing practice of 'judicial interpretational statements', 'issued by supreme courts on a specific legal issue in order to unify the conflicting case law', which are said to be 'unknown in western legal cultures' (p. 218). Although they are not formally binding today, 'they naturally possess a high degree of persuasive force throughout the judicial system' (p. 218). ${ }^{32}$ They 'are decided in abstracto, upon the motion of the Court, minister of justice or similar authority, when these bodies opine that the interest of uniform case law so demands' (p. 218). According to Kühn, 'western judges react to this post-communist institution with a mixture of surprise and embarrassment, because they view it as in conflict with their ideal that the judiciary makes law only through deciding cases, "interstitially," as Justice Holmes once famously noted, not through making law in abstracto' (p. 219).

With all respect to 'western judges', 33 I seriously doubt, that the 'western ideal' of judicial law making corresponds to Holmes' celebration of case-by-case

\footnotetext{
29 See Brian Tamanaha, Beyond the Formalist-Realist Divide: The Role of Politics in Judging (Princeton and Oxford: Princeton University Press 2010).

${ }^{30}$ Hans-Peter Haferkamp, Georg Friedrich Pucbta und die "Begriffsiurisprudeñ”" (Franfurt am Main: Vittorio Klostermann 2004), 26 actually ascribes the authorship of the term to Jehring. On the German critique of Begriffjurisprudenz see Tuori, n 28, 114-117.

31 On Pound in this context see Tamanaha, n 29, 27-43.

32 One may wonder what kind of 'persuasive force' Kühn has in mind, if he insists that post-communist law does not distinguish between anything but binding/non-binding.

33 They were in fact judges from Germany participating in a twinning project in the Czech Republic. Kühn refers to their unpublished report, 'Souhrn návrhů pro českou justici v oblasti organizace soudnictví, civilního a trestního rúzení' ['A Set of Proposals for the Czech Judiciary the Area of organization of the Judiciary and Civil and Criminal Procedure'], Twinning Project CZ 01/IB/JH/01 Judicial Reform and Court Management Czech Republic - Germany - United Kingdom.
} 
adjudication or that it would entail 'proper judicial law-making', as Kühn suggests (p. 219), although I agree that the power of the Minister of Justice to seek such interpretative statements can be quite problematic. Abstract law making by courts, however, is quite common in both continental Europe (think of different abstract procedures before constitutional courts or the preliminary ruling procedure before the ECJ) and Anglo-American law (here one can refer to the debate on the 'the rise of unnecessary constitutional rulings' and 'formulaic constitution'). ${ }^{34}$ Some scholars 'in the West' even found the judicial interpretational statements quite attractive, corresponding to their conceptualization of judicial law making and precedent, which builds on centuries-long experience with that type of law in Europe, called 'legislative precedent. ${ }^{35}$

'Western law' is presented as a unitary block and then imposed on postcommunist legal culture as a norm. This is quite obvious when Kühn for example notes that the continuing denial of the binding force of precedent 'would not, in itself, be tragic because such a view is not uncommon even in western Europe' (p. 217). So 'ignorant' socialist (and post-communist) lawyers are allowed to have some outdated opinions, since we can find them in the West too - but only to an extent, since they 'are increasingly criticized as not being sophisticated enough' ( $p$. 217). The West is the measure of everything.

\section{ON 'MISSIONARIES, CONVERTS, AND "LOCAL SAVAGES”}

This is perhaps the most troubling feature of the book, together with its confrontational style. The author acts as a 'missionary' bringing the light of the West to the 'local savages' in post-communist Europe. ${ }^{36}$ This style was quite effective in implementing reforms western-style when post-communist countries wanted to catch up with the West in order to get 'back to Europe'. It also very quickly bolstered those who were able to use it a powerful voice in the struggle for reform.

Those reforms were certainly needed, and Kühn is quite right when he identifies numerous problems of the post-communist judiciary. The problem with Kühn's prescriptions and the way he presents them is that the one-sided presentation of the West picks up just that part of the western reality which is suitable for the one using it and prevents any real discussion. It is simply not 'cool' to question the law making power of courts, the basic tenets of 'new constitutionalism', such as the widespread use of the proportionality argument and

\footnotetext{
34 See Thomas Healy, 'The Rise of Unnecessary Constitutional Rulings' (2005) 83 North Carolina Law Review 847 and Robert Nagel, 'Formulaic Constitution', (1985) 84 Michigan Law Review 165.

35 See particularly Fréderic Zénati, La jurisprudence (Paris: Dalloz 2001), 214. On the legislative model of reasoning with previous decisions see Komárek, n 23.

36 See András Sajó, 'Universal Rights, Missionaries, Converts, and "Local Savages"” (1997) 6 East European Constitutional Review 44.
} 
less and less weigh being given to legal texts at the expense of free-standing evaluations of law's purposes. While these things are debated in the West and are far from settled, in Central Europe much of the debate is muted precisely because a one-sided view of the West is used as an authority to tame 'local savages' expressing doubts.

When some authors in the East identify such debates and problems, their findings are devaluated by Kühn. When for example the Soviet legal theorist Vladimir Tumanov criticizes the rise of judge-made law in a book published in 1974, Kühn mentions 'a sophisticated leftist view' presented by Ron Hirschl and says: 'basic ideas are similar, although Hirschl's claims are much more persuasive than those which Tumanov made in dogmatic communist language' (p. 140, fn. 301). No matter that Hirschl's book was published thirty years later, no matter that Tumanov's book is explicitly entitled Contemporary Bourgeois Legal Thought: A Marxist Evaluation of the Basic Concepts and thus formulated in the language of the Marxist analysis, which Kühn seems not to take seriously throughout the book. ${ }^{37}$

Similarly, when a 'sophisticated socialist author's' critique of the same phenomenon 'might be supported by contemporary critics' (p. 139, Kühn refers to Unger), 'it is very different to argue in this way in the atmosphere of doctrinal western pluralism, on the one hand, and in a state of a one-party dictatorship, on the other' (p. 139). In other words, no matter how hard you try, you will always remain dogmatic, old-fashioned and ignorant (all these adjectives are used by Kühn). You can never have a proper voice of your own or be trusted that you genuinely believed in your visions grounded in socialism and communism.

Eörsi's prescription can be based on naïve belief in the legislator, who operates in a society that is internally much more coherent and thus able to determine what is in society's interest, ${ }^{38}$ but is Dworkin's idea of 'law as integrity', justifying the law making power of judges with reference to the shared liberal principles, in any way less? ${ }^{39}$ These critiques (together with a significant part of current jurisprudence and political theory, which is far less pessimistic about legislators) are never mentioned in Kühn's sweeping critique of socialist law and its scholars.

This relates to the wider problem of the 'ideology called transitology', ${ }^{40}$ of which the book is a good example: unwillingness to take the communist past seriously. The Croatian writer Boris Buden recalls the French philosopher Jean-

\footnotetext{
37 Interestingly, some people 'in the West' have found Tumanov's book rather good. See e.g. a book review by Toby Terrar, (1981) 26 American Journal of Jurisprudence 228.

${ }^{38}$ In fact, sociologically speaking, it would be hard to deny that the societies in Central Europe during communism were much more coherent than those in the West, especially since the late 1970s.

${ }^{39}$ See Andrew Altman, 'Legal Realism, Critical Legal Studies, and Dworkin' (1986) 15 Pbilosophy and Public Affairs 205.

40 Boris Buden, 'Children of Postcommunism' (2010) Radical Philosophy No. 159, 18-25, which is the English translation of chapter 2 of Buden's Zone des Übergangs: Vom Ende des Postkommunismus (Frankfurt am Main: Suhrkamp 2009).
} 
Luc Nancy's anger over the belief that 'history is finally finished with Marxism and communism':41

As if thousands of so-called "intellectuals" were simply fools, and especially as if millions of others were even more stupid as to have been caught in the delirium of the first. Even if we agree that it was a question of error and blindness (certainly stupidity and charlatanry are never absent from human affairs), such a degree of success must in and of itself raise problems for thought. ${ }^{42}$

This results in presenting Communism as something external, imposed from the barbaric East, rather than as something that was genuinely believed in by many people after the horrors of the World War. It also exonerates the 'democrats' of the post-war era, whose contribution to the decline of Central Europe was not negligible. ${ }^{43}$ The missionaries having the 'right' vision of law and politics then 'struggle' with the 'reactionary forces', rather than engaging them in a common project. The words of the former Vice-President of the Czech Constitutional Court Eliška Wagnerová, 'that there were only fifteen people at the Constitutional Court fighting the remainder of the professional legal community' (p. 230) are quite indicative of this mode of 'debate'. In fact it is the same kind of mentality these people say they want to overcome: one person knowing the right way, not willing to discuss its correctness with others, only fighting them. Some people are thus even not considered qualified anymore to contribute to the debate. ${ }^{44}$

The book thus provides a powerful testimony to the post-1989 struggles for reform. This, in my view, explains the book's shortcomings. Its ambition was primarily to serve as a blueprint for reform, and as such it was immensely successful, at least in the Czech Republic. ${ }^{45}$ It should not be taken as a final analysis of Central European legal culture however: that is yet to be written.

\footnotetext{
${ }^{41}$ Ibid.

${ }^{42}$ Jean-Luc Nancy (Tracy B. Strong transl.), 'La Comparution/The Compearance: From the Existence of "Communism" to the Community of "Existence"" (1992) 20 Political Theory 371-398, 376.

${ }^{43}$ See text to $n 20$.

${ }^{44}$ The editors of a monument volume Michal Bobek, Pavel Molek, Vojtěch Šimíček (eds), Komunistické právo v Ceskoslovensku: Kapitoly z déjin bezpráví [Communist Law in Czechoslovakia - Chapters from the History of Lawlessness], (Brno: Masarykova Universita 2009) note that they consciously did not include authors who were active in academia before 1989, since their generation is 'unfortunate' and even 'lost'. They suggest, in essence, that these people are not able to reflect on their past and therefore not invited to the debate on it.

45 The Czech version of the book under review, based on a doctoral (SJD) thesis defended at the University of Michigan School of Law in 2006, was first published in Czech translation as early as in 2005: See Aplikace práva soudcem v ére stredoevropskébo komunismu a transformace: Analýza pričín postkomunistické prámi krize [Application of Law by the Judge in the Era of Central-European Communism and Transformation: An Analysis of Causes of the Post-Communist Legal Crisis] (Prague: CH Beck 2005).
} 